\title{
QUANTITATIVE ANALYSIS OF A STONE RUN IN VITOSHA MOUNTAIN
}

\author{
DOI: http://dx.doi.org/10.18509/GBP.2020.17
}

UDC: $551.435 .58: 552.12(497.2)$

\section{Petko Bozhkov}

Sofia University “St. Kliment Ohridski”, Faculty of Geology and Geography, Department of Landscape Ecology and Environmental Protection, Bulgaria

\begin{abstract}
The aim of the following study is to analyze quantitatively the size, shape and form of boulders in stone runs in Vitosha Mountain. These landforms are common periglacial features in the alpine and subalpine zone of Bulgaria. Despite the precise descriptions and discussions about the genesis of stone runs in Vitosha Mountain, there is not enough data about the dimensions of the comprising boulders. The selected stone run is located in a touristic area of Vitosha Natural Park. The boulders occupy the uppermost valley of Yanchovska River between 1907 and $1764 \mathrm{~m}$ above sea level.

Rock boulders and blocks are measured in two key sites (T1 and T2) representing rock outcrops of monzonite. Every particle is characterized by measuring its longest (a), intermediate (b) and shortest (c) axis. The total number of sampled boulders is 120 . Several shape indices are calculated - sphericity, elongation index, flatness index etc. Particle morphology is related with petrography, weathering processes and the mode and duration of transport and deposition.
\end{abstract}

Keywords: particle morphology, roundness, sphericity, stone runs, Vitosha Mountain.

\section{INTRODUCTION}

Stone runs [1], also known as "block/rock streams" or "kurums" [2], are typical landforms in the alpine and subalpine zone of Bulgaria. Their local name could be translated in English as "stone rivers". They are defined as linear deposits of rock debris with downslope alignment which occupy some hill slopes and valley axes, formed in periglacial environments [2]. Despite their proximity with block fields, talus cones and rock falls, stone runs are not related with weathering scarps and vertical rock faces [1]. The stone runs in Vitosha Mountain are formed in the valleys of the rivers Yanchovska, Bistrishka, Struma, Varla, Matnitsa, Tanchovitsa, Rudaritsa, Bistra, Vladayska and others. According to some Bulgarian researchers [3], [4] the formation of stone runs is determined by the rock texture, microtectonics and periglacial climate conditions. According to another opinion [5] some stone runs in Vitosha are result of glacier transport during the Pleistocene and only those rock boulders around the summit of the mountain (Cherni vrah, $2290 \mathrm{~m}$ ) are with periglacial genesis. Despite the precise descriptions and discussions about the formation of stone runs in Vitosha Mountain, there is not enough data about the dimensions of the comprising boulders. Such data are complementary to information on the stone rivers and the processes that led to their formation.

The aim of the following study is to analyse quantitatively the size, shape and form of boulders in selected stone run in Vitosha Mountain. To achieve this, two key sites (T1 and T2) were chosen for performing a particle shape analysis. Each site is represented by a sample of individual measurements of boulders within defined area, which are compared by descriptive statistics. 


\section{LOCATION OF THE STUDY AREA}

The study area represents a typical stone run in Vitosha Mountain, located is western part of Bulgaria and south from the capital city of Sofia (Fig. 1). The selected stone run is located in a touristic area of Vitosha Natural Park, next to Aleko Hut - one of most visited locations in the mountain. The landform occupies the upper parts of the catchment area of Yanchovska River (left tributary of Bistritsa River). The stone river is developed between 1907 and $1639 \mathrm{~m}$ above sea level and is about $1.235 \mathrm{~km}$ long. The mean slope of the linear landform is $12-13^{\circ}$ and its width varies from few meters up to $70-80 \mathrm{~m}$. The stone river can be described as a river bed filled with boulders that some researchers used to refer as moraine materials [5]. The river is formed by several tributaries, each of which is filled with monzonite boulders. The streams flow beneath those rock fragments transporting finer materials (pebbles, gravel, sand). The spaces between individual boulders are usually hollow, which is prerequisite for vertical circulation of air, infiltration of rain and retention of snow patches. Usually stone runs are hard to cross by foot and form a distinct landscape (Fig. 2 and 3). Monzonite blocks are exposed to weathering, especially during the winter season when ice wedges are formed in the rock crack.

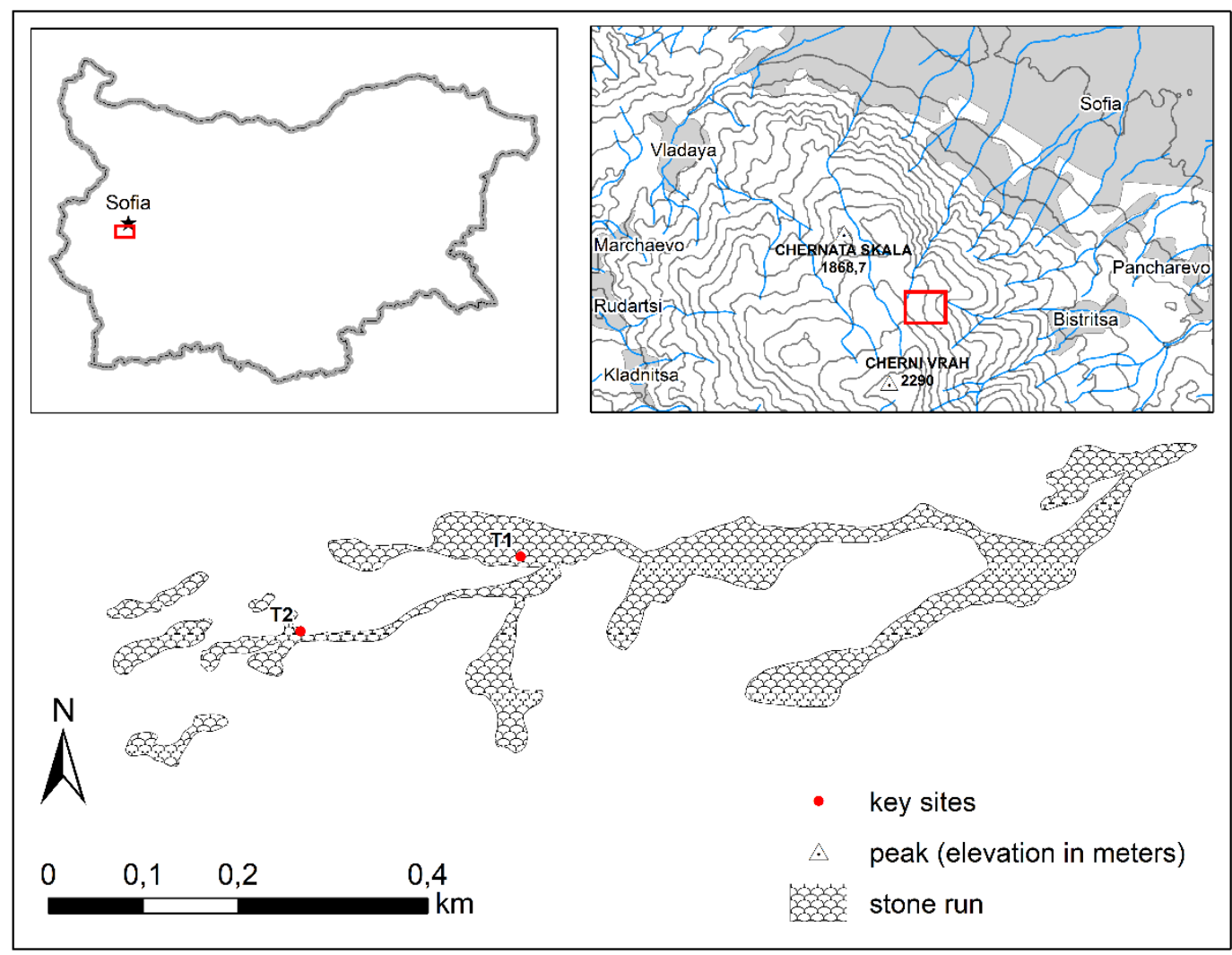

Fig. 1. Location of the study area and key sites 


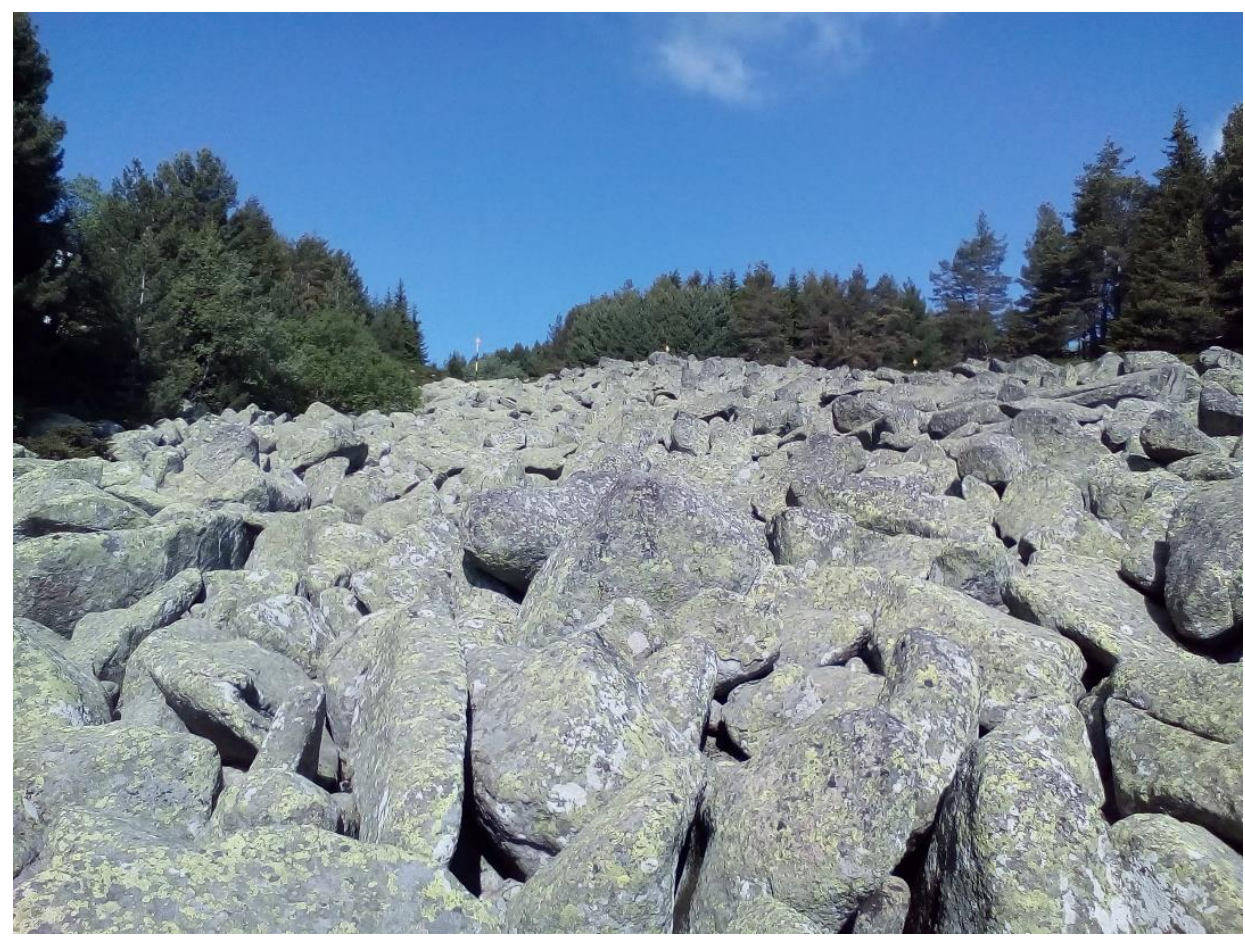

Fig. 2. Stone run near Aleko Hut (key site T1)

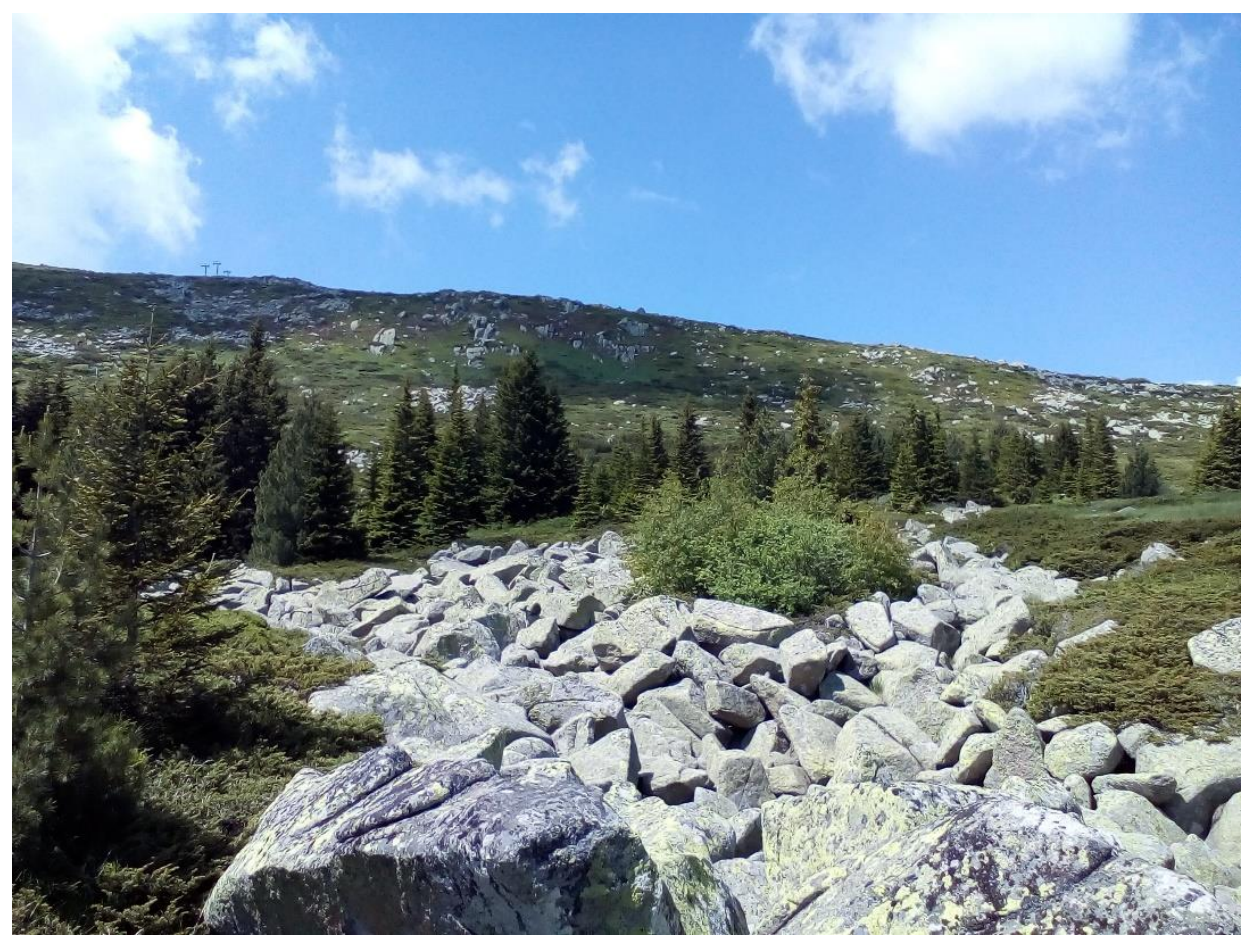

Fig. 3. Stone run near Aleko Hut (key site T2)

\section{MATERIALS AND METHODS}

Particle shape depends on lithology, particle size, the mode and duration of transport, the energy of the transporting agent, the nature and extent of post-depositional weathering, and the history and length of sediment transport and re-deposition.

Key sites T1 and T2 are located under similar topographic conditions in different parts of the stone river (Figs. 1). In each site, 60 rock boulders were measured along axes a (long), 
b (intermediate) and c (short) axis using measuring tape. Measurements are taken with the precision of $1 \mathrm{~cm}$ due to the sizes of the rock debris. Only particles over $10 \mathrm{~mm}$ in diameter are measured. Finer particles can be studied with grain size (sieve) analysis. Using the input data on axial length are calculated standard shape indices - sphericity [6][7], flatness [8], elongation [9], isometricity [10] (Table 1). The results of the measurements are presented in Table. 1.

To classify the shape of each boulder (spheroids, discoids, rods, or blades) two ratios are used $-\mathrm{b} / \mathrm{a}$ and $\mathrm{c} / \mathrm{b}$ [11]. The roundness of each boulder is determined visually in the field using a 5-grade classification system - very angular (0-roundness), angular (1), subangular (2), subrounded (3), rounded (4), broken particles (5) [12]. The mean roundness is calculated as an average of all sampled boulders.

Table 1. Used morphometric (shape) indices

\begin{tabular}{c|c|c}
\hline Index & Formula & Author(s) \\
\hline Sphericity & $\psi=\sqrt[3]{\left(b c / a^{\wedge} 2\right)}$ & Krumbein [6] \\
\hline Sphericity & $\psi=\sqrt[3]{\left(c^{\wedge} 2 / a b\right)}$ & Sneed, Folk [7] \\
\hline Flatness & $F=((a+b) / 2 c)$ & Cailleux [8] \\
\hline Elongation & $a / b$ & Cailleux [9] \\
\hline Isometricity & $F=((a+c) / 2 b)$ & Serebryanny [10] \\
\hline Shape ratios & $b / a ;$ & Zing [11] \\
\hline
\end{tabular}

\section{RESULTS AND DISCUSSION}

Analysis of the particle diameters showed no significant differences in boulder sizes from the selected parts of the stone run. Dominant rock fragments in both sites (T1 and T2) have rounded shape and average dimensions along the intermediate axis " $b$ " about $1 \mathrm{~m}$ in length (table 1). The largest boulder in key site T1 is determined to be $381 \times 144$ x 110 $\mathrm{cm}$, and in site T2 the rock debris reaches $450 \times 230 \times 127 \mathrm{~cm}$. However, the average sizes of blocks in site T1 are larger than those of site T2 (table1).

The high standard deviation of each axis (table 1) indicates that the values are spread out over a wider range which is expected due to the difference between minimal and maximum sizes of the boulders.

Table 2. Results of particle shape analysis of boulders in sites T1 and T2

\begin{tabular}{ccc}
\hline & $\mathrm{T} 1$ & $\mathrm{~T} 2$ \\
\hline Count & 60 & 60 \\
Minimum $(\mathrm{cm})$ & $\mathrm{a}-58 ; \mathrm{b}-40 ; \mathrm{c}-12 ;$ & $\mathrm{a}-39 ; \mathrm{b}-29 ; \mathrm{c}-8$ \\
Maximum $(\mathrm{cm})$ & $\mathrm{a}-381 ; \mathrm{b}-230 ; \mathrm{c}-112$ & $\mathrm{a}-450 ; \mathrm{b}-230 ; \mathrm{c}-127$ \\
Average $(\mathrm{cm})$ & $\mathrm{a}-176 ; \mathrm{b}-105 ; \mathrm{c}-60$ & $\mathrm{a}-143 ; \mathrm{b}-93 ; \mathrm{c}-50$ \\
Standard deviation & $\mathrm{a}-72 ; \mathrm{b}-43 ; \mathrm{c}-24$ & $\mathrm{a}-70 ; \mathrm{b}-47 ; \mathrm{c}-26$ \\
Predominating petrography & Monzonite & Monzonite \\
Mean roundness & 4.1 & 4.2 \\
Brocken boulders (\%) & 13 & 15 \\
Transported by dragging (\%) & 64 & 73 \\
Transported by saltation (\%) & 38 & 27 \\
Sphericity [1] & 0.60 & 0.61 \\
Sphericity [2] & 0.59 & 0.58 \\
Flatness index [3] & 2.49 & 2.62 \\
Elongation index [4] & 1.76 & 1.64 \\
Isometricity [5] & 1.18 & 1.10 \\
\hline
\end{tabular}


Roundness and sphericity are two of the most common shape indices. The boulders in site T1 are well rounded, with fifty-one being of grade 4 roundness. Most boulders are covered with lichens in places. In several blocks, fresh rock surfaces are observed as a result of spherical and frost weathering. The broken pieces (grade 5) are 8 pieces or about $13 \%$ of all measured boulders (table 1). Seven of them are rounded to the 4th degree on one side, and from the broken one, a fresh rock surface without or with lichens is exposed. The broken blocks (grade 5) are 8 or about $13 \%$ of all measured boulders. Seven of them are rounded to the 4th degree on one side, and from the broken one, a fresh rock surface without or with lichens is exposed. In site T2, rock debris with similar degrees of roundness is observed. Rounded blocks of grade 4 (51 in total or $85 \%$ of all measured) are the dominant ones. In one of them are visible cracks along the axes "a" and "b".

Due to the large proportion of broken blocks (Grade V), the average roundness of boulders in site $\mathrm{T} 1$ is 4.1 and in site $\mathrm{T} 2$ it is 4.2 . The large proportion of broken pieces in the composition of the stone run is explained by frost weathering; the presence of systems of joints in which water could freeze and the force of gravity. Presumably, some of these blocks are broken by their own weight or the weight of the surrounding blocks.

Sphericity values range from 0 (nonspherical) to 1 (perfect sphere). All of the measured boulders fall in the range of 0.31 to 0.97 . The mean sphericity of each sample (T1 and T2) is about 0,6 despite the used calculation method (table 1). Possibly, this value is determined by the spherical (spheroidal) weathering of the igneous rocks.

The flatness ranges from a minimum value of 1 (for an ideal particle) and becomes larger the flatter the particle. Boulders from the two sampled sites have similar mean flatness (table 1), which deviates from the ideal shape with flatness of 1.

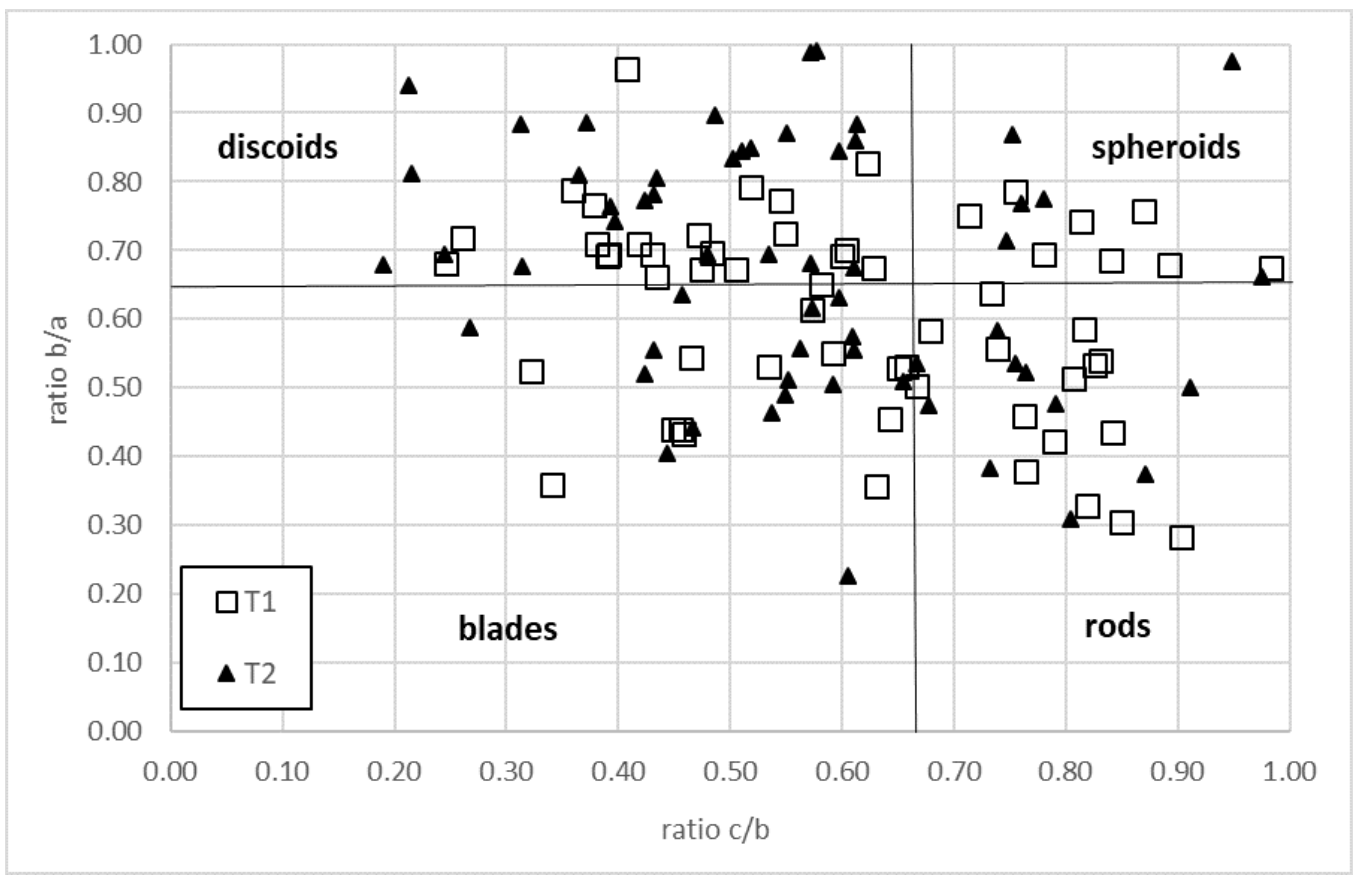

Fig. 4. Shape classification of boulders in sites T1 and T2

The elongation index is a relatively simple one. The greater the value of elongation the greater the clast length. In site T1 elongation index varies between 0,98 and 3,55, while in site $\mathrm{T} 2$ it is in the range of 1.01 to 4.42 . Although the presence of significantly elongated blocks, the mean elongation in each site is about 1,7 (table 1). 
Isometricity indicates the degree of difference in the length of the three axes ( $a, b$ and $c)$. Ideal spherical body $(\mathrm{a}=\mathrm{b}=\mathrm{c})$ has an isometric index of 1 . The boulders of site $\mathrm{T} 1 \mathrm{has}$ isometricity between 0.65 and 2.23. A similar range is determined in site $\mathrm{T} 2$ - isometricity from 0.64 to 2,51 . Despite the wide ranges, the average values are close to 1 . The mean values of elongation and isometricity could be explained by the rounded shape of most boulders, which is close to an ellipsoid or a spheroid.

The predominant shape of measured boulders in both sites is discoid (23 in site T1 and 27 in site T2 respectively), followed by the blades and rod-like ones (Fig. 4). The last ones are almost equal in the sample $\mathrm{T} 1$, whereas in site $\mathrm{T} 2$ rods are less than blades. The spheroids are the least common shape among all 120 sampled boulders (Fig. 4).

\section{CONCLUSION}

The analysis of the quantitative and qualitative characteristics of the boulders showed that there were no significant differences in the size of the debris forming separate sites of the studied stone run. There are no visible traces of transport activity (for example running water or glacier), which means that the rocks disintegrate in place (in situ weathering). This is confirmed by the observations made in the field (the formation of grus in site T1). Therefore, stone runs or (stone rivers in Bulgarian) are periglacial landforms formed at the expense of frost and spherical weathering (typical for igneous rocks) and modeled also by flowing water. It is the fluvial processes that transport the weathered material, and during the winter months when the river water freezes, the ice in the river bed acts as a weathering agent on the covering blocks.

Stone rivers in the basin of the Yanchovska River are periglacial forms that are still developing today under the influence of the weathering and denudation processes. The obtained results can be compared with analyses of similar landforms in other Bulgarian mountains such as Rila and Pirin.

\section{Acknowledgments}

This publication is part of a project titled "Weathering and slope processes, landforms, and deposits in Vitosha Mountain" funded by The National program "Young scientists and Postdoctoral candidates" 2020 of Ministry of Education and Science of Bulgaria

\section{REFERENCES}

[1] Washburn, A. L. Periglacial Processes and Environments. London, Edward Arnold; New York, St. Martin Press, 320 p., 1973.

[2] Wilson, P. Block/Rock Streams, in Encyclopedia of Quaternary Science, Elsevier, Editors: S. A. Elias, pp.2217-2225, 2007.

[3] Georgiev, M. Geomorphology of the north and northwest slope of Vitosha Mountain, Ann. Sofia Univ. vol. 58, 2, pp.13-51, 1965. (in Bulgarian with French abstract).

[4] Glovnya M. About the periglacial relief in Bulgaria. Reviews of Bulg. Geogr. Soc., vol. 2, pp. 5-15, 1959. (in Bulgarian with French abstract)

[5] Hristov, R. Geological and geomorphological research on Vitosha Mountain. Ann. Inst. Mining and Geology, vol. 5, 2, pp. 225-259, 1958. (in Bulgarian with French abstract)

[6] Krumbein, W. C. Measurement and geological significance of shape and roundness of sedimentary particles. J. Sedim. Petrol., 11, pp. 64-72, 1941.

[7] Sneed, E. D., R. L. Folk. Pebbles in the lower Colorado River, Texas. A study in particle morphogenesis. J. Geol., 66, pp. 114-50, 1958. 
[8] Cailleux, A. Distinction des galets marins et fluviatiles. Societe Geologique de France Bulletin 15, pp. 375-404, 1945. (in French)

[9] Cailleux A. L'indice d'émoussé des grains de sable et grès. Revue De Géomorphologie Dynamique. 3, pp.78-87, 1947. (in French)

[10] Serebryanny. L. R. Laboratory analysis in geomorphology and Quaternary paleo-geography. Series Geomorphology, 6, 152 p., 1980. (in Russian)

[11] Zingg, Th. Beiträge zur Schotteranalyse. Min. Petrog. Mitt. Schweiz., 15, pp. 39-140, 1935. (in Deutsch)

[12] Habakov A.V. On the roundness indices of pebbles. Soviet geology, 10, pp. 98-99, 1946. (in Russian) 